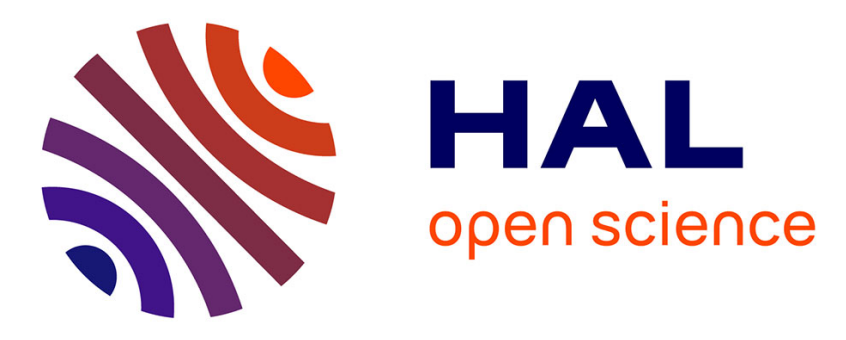

\title{
Catalytic hydrothermal conversion of algal residue to bio-bitumen
}

\author{
Laura Carolina Cardenas Velandia, Anne Elisabeth Fontaine, Denis Loquet, \\ Ruben Checa, Chantal Lorentz, Bruno Bujoli, Nolven Guilhaume, Christophe \\ Geantet, Emmanuel Chailleux, Clémence Queffelec, et al.
}

\section{To cite this version:}

Laura Carolina Cardenas Velandia, Anne Elisabeth Fontaine, Denis Loquet, Ruben Checa, Chantal Lorentz, et al.. Catalytic hydrothermal conversion of algal residue to bio-bitumen. Journal of Cleaner Production, 2021, 322, pp.129024. 10.1016/j.jclepro.2021.129024 . hal-03373052

\section{HAL Id: hal-03373052 https://hal.science/hal-03373052}

Submitted on 11 Oct 2021

HAL is a multi-disciplinary open access archive for the deposit and dissemination of scientific research documents, whether they are published or not. The documents may come from teaching and research institutions in France or abroad, or from public or private research centers.
L'archive ouverte pluridisciplinaire HAL, est destinée au dépôt et à la diffusion de documents scientifiques de niveau recherche, publiés ou non, émanant des établissements d'enseignement et de recherche français ou étrangers, des laboratoires publics ou privés. 


\title{
Catalytic Hydrothermal Conversion of Algal Residue to bio-Bitumen
}

Laura Carolina Cardenas Velandias, ${ }^{1}$ Anne Elisabeth Fontaine, ${ }^{2}$ Denis Loquet, ${ }^{2}$ Ruben Checa, ${ }^{1}$ Chantal Lorentz, ${ }^{1}$ Bruno Bujoli, ${ }^{2}$ Nolven Guilhaume, ${ }^{1}$ Christophe Geantet, ${ }^{1}$ Emmanuel Chailleux, ${ }^{3}$ Clémence Queffélec ${ }^{2 *}$ and Dorothée Laurenti ${ }^{1 *}$

1. IRCELYON, UMR 5256, CNRS-Université de Lyon 1, 2 av. Albert Einstein, 69626 Villeurbanne Cedex, France

2. Université de Nantes, CNRS, CEISAM, UMR 6230, F-44000 Nantes, France

3. Ifsttar / Centre de Nantes, Département MAST / Laboratoire Matériaux pour les Infrastructures de Transports, Route de Bouaye CS4, 44344 Bouguenais, France

\begin{abstract}
After extraction of high-added value components of Spirulina sp., the remaining residues can be valorized by hydrothermal liquefaction to produce an oily water insoluble viscous phase (biocrude) which is very similar to petroleum bitumen. This hydrophobic fraction is composed of various $\mathrm{N}-, \mathrm{O}$-containing cyclic compounds, fatty acids, amides, nitriles, alkenes and alkanes. In order to optimize the rheological properties of the biocrude, we studied the addition of different catalysts with various loadings: $\mathrm{ZrO}_{2}$ or $\mathrm{CeO}_{2}$, or $\mathrm{Ce}\left(\mathrm{NO}_{3}\right)_{3} \cdot 6 \mathrm{H}_{2} \mathrm{O}$ as well as the effect of residence time during HTL. The biocrude has been systematically characterized by GCxGC, GPC, elemental analyses and dynamic shear rheology and compared to a petroleum bitumen. The different catalysts tested had little influence on the composition of the HTL hydrophobic fraction in the chosen operating conditions. In contrast, increasing the reaction time (from 1 to $7 \mathrm{~h}$ ) was found to promote condensation reactions, thereby increasing the average molecular weight of the biocrude, leading to a viscoelastic material very similar to a petroleum bitumen.
\end{abstract}

Key-words: Microalgae, Hydrothermal Liquefaction, Oxide Catalysts, Bio-binders, Bitumen

\section{Introduction}

Similarly to transportation fuels, alternatives bio-resources have to be investigated for the production of bitumen substitutes in order to be more sustainable and address the uncertainty of the fossil feedstocks. Recently, it has been shown that the hydrophobic fraction obtained by hydrothermal liquefaction (HTL) of Scenedesmus sp.[1] or Spirulina sp. residues 
[2] could be successfully used in this goal. Effectively, HTL conversion of Scenedesmus sp. residues led to a viscous hydrophobic phase that presented rheological properties similar to those of a conventional bitumen. In contrast, spirulina residues led to an oily phase similar to an elastomer-rich bitumen, in terms of viscoelastic properties. Very recently, lignocellulose[3] or food waste[4] were transformed by HTL and the obtained bio-oil were mixed at various percentage with conventional asphalt binders and their rheological properties were closed with those of petroleum-based asphalt.

In the literature, many catalysts have been investigated during HTL conversion and they were shown to affect the composition of the hydrophobic phase that lead in some cases to new interesting properties. The different catalysts previously used in HTL were either homogeneous (water soluble) or heterogeneous (water insoluble) catalysts.[5] Homogeneous catalysts were mainly water alkali salts or organic and inorganic acids [6]. One of the most commonly used is sodium carbonate $\left(\mathrm{Na}_{2} \mathrm{CO}_{3}\right)$ that usually increases the overall biocrude yield by promoting the decomposition of carbohydrates [7-9], although it may also induce saponification reactions in the presence of lipids $[9,10]$. As regards heterogeneous catalysts, supported metals, metal oxides and zeolite catalysts were widely used in the HTL treatment of microalgae for biofuels production. For this application, the main goal is to improve the yield of the oily phase by decreasing the size of its molecular components and to reduce its oxygen and nitrogen contents[8,11-18]. According to Galadima and Muranza, the main role of heterogeneous catalysts in this case is to promote rapid bond cleavages, allowing the production of light molecular weight compounds[19].

The novelty of the present study is to assess the effect of different catalysts on the rheological properties of the biocrude obtained after HTL from algal residues. objective of the present study was to produce bio-bitumen, high molecular weight constituents have to be preserved to provide a suitable viscosity and rheology of the bio-oils. For this purpose, we wished to increase the carbon chain size and also to remove some heteroatoms and small molecules. For instance, the coupling of two carboxylic acids via a ketonization reaction might produce longer chains ketones or hydrocarbons $[14,20]$. Therefore, promoting ketonization reactions through the use of a catalyst seemed appropriate since these reactions have been reported as a possible pathway to obtain high molecular weight compounds, through the reactive condensation between two carboxylic acids or esters that are converted into a linear ketone with the loss of carbon dioxide and water [21]. Ceria- 
zirconia mixed oxides were successfully used for bio-oil upgrading [22]. For example, Lee et al.[23] have reported the ketonization reaction of hexanoic acid to obtain 6-undecanone and investigated the performances of different catalysts: silica-alumina, $\mathrm{Al}_{2} \mathrm{O}_{3}, \mathrm{TiO}_{2}, \mathrm{ZrO}_{2}, \mathrm{CeO}_{2}$, $\mathrm{MgO}$ and $\mathrm{MnOx}$. The basic oxides $\mathrm{MgO}$ and $\mathrm{MnOx}$ were found the most active but resulted in a high leaching of metal cations in the reaction medium and a deactivation of the catalyst. Various zirconia catalysts were then tested including sulfated, aerogel and xerogel zirconias and classical low surface area zirconia [23]. The amphoteric character of $\mathrm{ZrO}_{2}$ led to higher conversions without leaching, especially in the case of high surface area.

In this work, HTL experiments were performed on new Spirulina residues, called Spirugrass, and the influence of several type of catalysts was investigated, including oxides like such as $\mathrm{ZrO}_{2}$ or $\mathrm{CeO}_{2}$ known to promote ketonization reaction, or salts such as $\mathrm{Ce}\left(\mathrm{NO}_{3}\right)_{3} \cdot 6 \mathrm{H}_{2} \mathrm{O}$ which is soluble in water and can be transformed in situ into cerium oxide under HTL operating conditions. The chemical characterization of the resulting hydrophobic fraction was carried out using various advanced techniques, such as bi-dimensional gas chromatography (GCXGC) with MS and Fl detectors, elemental analysis (CHNS-O), gel permeation chromatography (SEC/GPC). Finally, the rheological properties of the different hydrophobic fractions were measured and compared to a conventional petroleum bitumen.

\section{Materials and methods}

\subsection{Materials}

The Spirulina sp. residue, so called "Spirugrass" was provided by the AlgoSource company (Alpha-Biotech, Asserac, France). AlgoSource markets Spirulina sp. extracts as food supplement. In a typical process, the crude Spirulina biomass is harvested, freezed, brought back to room temperature and centrifuged. The aqueous supernatant which contains about $50 \mathrm{wt} . \%$ of the initial dry biomass is mainly composed of proteins, carbohydrates and mineral salts, but no lipid. After a purification process which is kept confidential, the resulting drinkable solution is commercialized as food complement with a guaranteed phycocyanin content $(0.08 \mathrm{wt} . \%)$. After the centrifugation step, a solid residue is obtained which is usually eliminated as a waste. The latter was used for this study and was freeze-dried prior to use. The Spirulina sp. composition can vary depending on the growth conditions; a representative example is: proteins (65 wt\%), carbohydrates (20 wt\%) and lipids (15 wt\%) [2]. 
This Spirugrass is a solid fraction waste which contains lipids. This solid was crushed and grinded to be used as feedstock in hydrothermal liquefaction experiments.

When performing the catalytic hydrothermal liquefaction of Spirugrass, one of the following catalysts was added: zirconium oxide $\left(\mathrm{ZrO}_{2}, \mathrm{Norpro}\right)$ which was crushed and sieved to obtain a particle size around $125-200 \mu \mathrm{m}$, cerium oxide $\left(\mathrm{CeO}_{2}\right.$, Solvay) already in powder form and cerium nitrate hexahydrate from Sigma Aldrich. Specifications of zirconium oxide and cerium oxide catalysts, such as specific surface area, are presented in Table 1. HPLC grade solvents (i.e. dichloromethane, tetrahydrofuran, chloroform, methanol...) used for products separation or analysis were obtained from Carlo Erba and used without further purification.

\subsection{Solvent extraction of microalgae residues}

In order to quantify the lipid fraction present in the spirugrass residue, solvent extraction was carried out using a Velp Scientifica SER 158 automatic solvent extractor. For each extraction, approximately $10 \mathrm{~g}$ of crushed Spirugrass were deposited in a cellulosic thimble, then $100 \mathrm{~mL}$ of a chloroform-methanol mixture (2:1 in volume using the same mixture and proportion as Audo et al.[1] ), was placed in the beaker where the thimble was immersed. This apparatus works following 5 successive steps: immersion (50 min), removing (20 min), washing (30 min), recovery (30 $\mathrm{min})$ and cooling $(10 \mathrm{~min})$.

\subsection{Thermogravimetric analysis (TGA)}

The thermal decomposition of the residue was studied using a TGA/DTA SETARAM with a Setsys Evolution 12 apparatus. Approximatively $7 \mathrm{mg}$ of sample was deposited in a platinum crucible and heated up until $750{ }^{\circ} \mathrm{C}$ with a heating rate of $5{ }^{\circ} \mathrm{C} / \mathrm{min}$ under an air flow of 50 $\mathrm{mL} / \mathrm{min}$. The weight loss at $100{ }^{\circ} \mathrm{C}$ corresponds to the water content, whereas the remaining weight at the end of the measurement corresponds to the ash content.

\subsection{Gel permeation chromatography (GPC/SEC)}

The size exclusion analysis was carried out with an Agilent apparatus (1200 series) equipped with two PL gel porous columns of different porous size (500-50 ̊), using tetrahydrofuran (THF) as the mobile phase and a differential refractive index (DRI) detector. Each sample was diluted at $5 \mathrm{wt} \%$ in THF and filtered using a syringe filter with a pore size of $0.45 \mu \mathrm{m}$.

The system was calibrated using hydrocarbons $(\mathrm{HC})$ standards with a range of molecular weight from 86 to $1000 \mathrm{~g} / \mathrm{mol}$. The linear alkane calibration is more appropriate than usually used polystyrene standards taking into account the presence of fatty chains in the algal oil. 
However, because of the solubility of alkanes, this calibration ends at $1000 \mathrm{~g} / \mathrm{mol}$ which is not enough to evaluate the whole molecular weight distribution. Therefore, the distribution is not absolute, it is relative to the calibration curve. For an easier comparison, the chromatograms were normalized according to the most intense peak.

\subsection{Elementary analysis (CHNS-O)}

The $\mathrm{C}, \mathrm{H}, \mathrm{N}, \mathrm{O}$ and S content was measured using a Thermo Scientific Flash 2000 series CHNS/O Analyzer, equipped with a thermal conductivity detector (TCD). The analysis was performed twice for each sample. The $\mathrm{C}, \mathrm{H}, \mathrm{N}$ and $\mathrm{S}$ percentages were measured after a flash combustion of the sample, generating a gas mixture composed of $\mathrm{N}_{2}, \mathrm{CO}_{2}, \mathrm{H}_{2} \mathrm{O}$ and $\mathrm{SO}_{2}$, which flows through a GC column to be analyzed by the TCD detector. The oxygen content was measured separately, by the catalytic pyrolysis of the sample under $\mathrm{He}$, where $\mathrm{CO}$ is produced and quantified.

\subsection{Bi-dimensional gas chromatography (GCXGC)}

The analyses of the oily part of the hydrophobic fractions were carried out with an Agilent 6890 apparatus, equiped with a ZOEX thermal modulation system (cryogenic Nitrogen ). The modulation period was set to $11.63 \mathrm{sec}$.. The first column is a semi-polar capillary column ZB35 (phenomenex) of $30 \mathrm{~m}$ length ( $35 \%$ phenyl and $65 \%$ dimethylpolysiloxane) and the second one is a nonpolar capillary column DB-1 (Agilent) of $2 \mathrm{~m}$ length (100\% dimethylpolysiloxane). Two detectors were used to analyze the samples: mass spectrometry (MS) detector, carried out on a single quadrupole mass spectrometer Agilent 5975B, for qualitative analysis and flame ionization detector (FID) for quantitative analysis, where decane was used as internal standard (3-10 $\mu \mathrm{L})$. Samples were diluted in THF or DCM, in a weight percentage among 5-10 $\%$, and all the samples were filtered $(0.45 \mathrm{~mm})$ before the measurement. In the case of the hydrophobic phase and the extracts, the method was carried out with an injection volume of $0.5 \mu \mathrm{L}$ at $310^{\circ} \mathrm{C}$ and a split ratio of $50: 1$, while for the aqueous phase the injection volume was $0.1 \mu \mathrm{L}$ at $310^{\circ} \mathrm{C}$ and a split ratio of $10: 1$ (considering the expansion volume of water in the gas phase). The scan mass spectra were measured in the range of 33-280 m/z. The temperature program used for the analysis started at $50{ }^{\circ} \mathrm{C}$ for $5 \mathrm{~min}$., followed by a $2{ }^{\circ} \mathrm{C} / \mathrm{min}$ ramp to 350 ${ }^{\circ} \mathrm{C}$ for the first oven. The heating program of the second oven containing the second column was identical to the first oven. This equipment is controlled by Mass Hunter software (Agilent) and the $2 \mathrm{D}$ data were processed by GC-Image Software.

\subsection{Ashes composition}


The ash content residue obtained (orange) after TGA was characterized by scanning electron microscopy (SEM-EDX), in order to determine its qualitative composition and then ICP-AES was performed to quantify the identified elements.

\subsection{Elemental analysis SEM-EDX}

Scanning electron microscopy with energy dispersive x-ray spectroscopy (SEM-EDX) was performed on a JEOL JEM2010 apparatus, to identify the mineral content in the Spirugrass ashes.

\subsection{Elemental analysis ICP-AES}

The inductively coupled plasma with atomic emission spectroscopy (ICP-AES) technique was carried out on a Activa apparatus from Horiba Jobin Yvon, to quantify the various elements identified thanks to SEM-EDX of the Spirugrass ashes.

\subsection{Hydrothermal Liquefaction (HTL) experiments}

The hydrothermal liquefaction of Spirugrass was performed either (i) in a $300 \mathrm{~mL}$ or a 1000 $\mathrm{mL}$ stainless steel batch Parr reactor. Both reactors were equipped with a stirring and heating system composed of an electric oven covered with a glass wool jacket to reduce the heat losses. The pressure inside the reactor was measured through a manometer and the temperature was taken recorded inside the reacting solution, using a thermocouple system connected to the Parr 4842 controller.

Almost all experiments were performed under inert atmosphere $\left(\mathrm{N}_{2}\right)$ and following the same protocol: (i) in the $300 \mathrm{~mL}$ reactor (resp. $1000 \mathrm{~mL}$ ), $20 \mathrm{~g}$ of crushed Spirugrass (resp. $96 \mathrm{~g}$ ) and $80 \mathrm{~mL}$ of distilled water (resp. $385 \mathrm{~mL}$ ) were introduced corresponding to a ratio of $4 \mathrm{~mL}$ of water per gram of biomass. The reactor was degassed with a flow of $\mathrm{N}_{2}$ in order to remove the air and the oxygen possibly dissolved in water. Before heating the reactor, a leak test was carried using $\mathrm{N}_{2}$ to pressurize the system until around 50 bar for several minutes. Subsequently, the reactor was heated up to $260{ }^{\circ} \mathrm{C}$ (subcritical conditions, autogenous pressure of approx. $53 \mathrm{bar}$ ) with an approximate rate of $8{ }^{\circ} \mathrm{C} / \mathrm{min}$ and a stirring speed of 500 $\mathrm{rpm}$. Several reaction times were tested (between $15 \mathrm{mn}$ and $7 \mathrm{~h}$ ); at the end of the reaction, the heating was stopped and the system was cooled down to ambient temperature.

\section{Catalytic Hydrothermal Liquefaction (HTL) experiments}

Following the above protocol, various catalysts were added in the initial feed. The amount of catalyst is given based on the initial biomass, and the different assays are presented in Table 2. 
Experiments without catalysts and with cerium nitrate catalyst were repeated five times. The accuracy in yield determination was less than $3 \%$.

\subsection{Products recovery}

At the end of the HTL experiments, two distinct phases were obtained, the hydrophobic phase on the bottom of the reactor and the supernatant aqueous phase. The aqueous phase was directly transferred from the reactor to a storage flask and the sticky hydrophobic phase remaining in the reactor was recovered using dichloromethane. After this step, no filtration was done except for one experiment, which means that the solid fraction was left inside the hydrophobic phase. Subsequently, the solvent was evaporated under reduced pressure and the hydrophobic fraction was weighted to calculate the bio-oil yield, based on the initial biomass, applying equation 1 . When a catalyst was employed, as it remained mixed with the solid fraction, its initial mass was substracted to assess the reaction yield.

$$
\begin{aligned}
\text { Yield }= & (\text { Whydroph }- \text { Mcat }) /(\mathrm{Wi}) * 100 \quad \text { (Eq. 1) } \\
& \text { With Whydroph }=\text { Weight }(\mathrm{g}) \text { of the hydrophobic phase } \\
& \text { Mcat }=\text { Mass of catalyst introduced in the reactor }(\mathrm{g}) \\
& \mathrm{Wi}=\text { Mass of Spirugrass introduced in the reactor }(\mathrm{g})
\end{aligned}
$$

\subsection{Rheological analyses}

The rheological properties of the HTL hydrophobic fractions were measured with a Kinexus pro + rheometer in shear mode, according to the European Standard EN 14770. The samples were loaded, in the melted state at $100{ }^{\circ} \mathrm{C}$, on a plate-plate geometry (with a diameter of 8 $\mathrm{mm}$ ) with $1 \mathrm{~mm}$ gap. The phase angles $d\left(^{\circ}\right)$ and norm of complex modulus $\left(\left|G^{*}\right|\right)$ were measured using dynamic shear rheometry (DSR), at different temperature values (from $80^{\circ} \mathrm{C}$ to $0^{\circ} \mathrm{C}$ ) and at various frequencies (from $0.01 \mathrm{~Hz}$ to $10 \mathrm{~Hz}$ ). Measurements were performed in the small strain domain in order to remain in the linear viscoelasticity theory framework.

\section{Results and discussion}

\subsection{Spirugrass characterization and lipid extraction}

Spirugrass was characterized by elemental analysis and TGA to determine the CHONS, moisture and ashes content (Table 3 and Figure S1 in the Suppl. Inf.). After TGA, the recovered ashes of Spirugrass were analysed by SEM to identify the major inorganic elements that were then quantified using ICP-AES (Figure S2). The elements detected by SEM-EDX in ashes were mainly $\mathrm{Ca}$, Fe, $\mathrm{P}$ and $\mathrm{Si}$ and the ICP-AES measurement confirmed this result. The high content 
in Ca and P, respectively 21 and $10.4 \mathrm{wt} \%$, is attributed to the nutrients added during the growing phase of microalgae that are trapped in the wet initial biomass and subsequently concentrated in the dry residue.

Lipids extraction of Spirugrass in $\mathrm{CHCl}_{3} / \mathrm{MeOH}$ mixture $(2 / 1 \mathrm{v} / \mathrm{v})$ was carried out using a solvent extractor following Bligh and Dyer adapted procedure [24] and gave 16 wt\% yield after removal of the solvent under reduced pressure. This extract was analyzed by elemental analysis (CHONS content, Table 3), GPC and GCxGC-MS. The concentration of nitrogen (5.0 \pm $0.28 \mathrm{wt} \%$ ) in the extract might originate from phycocyanin (a blue pigment present in large amount in Spirulina sp.) and/or from chlorophyll as the colour of the extract is blue-green [25]. Figure S3 displays the GCxGC analysis of the volatile compounds present in the lipid-rich extract. As a general comment, few compounds were detected by GCxGC-MS because most of the extract is composed of non-volatile matter. As already reported by Paoletti for Spirulina sp. [26] the presence of alkanes was detected (i.e. pentadecane, hexadecane) among which heptadecane was one of the most abundant in this study. C16 and C18 carboxylic acids were the main other detected compounds $[27,28]$, with small amounts of unsaturated fatty alcohols and acetate. The 3D-view also given in Figure S3 allowed to evaluate the relative intensity of each corresponding peaks in relation with their concentration in the extract, showing that hexadecanoic acid is the main observable component.

The GPC molecular mass distribution of the Spirugrass extract (Figure S4) displayed with stearic acid (C18:0) and glycerylstearate (C57) as references, showed two main zones with the alkane calibration (HC equivalent). The first one, centred at $305 \mathrm{~g} / \mathrm{mol} \mathrm{HC}$ eq., included the stearic acid peak and can thus correspond to C16-C18 fatty acids and to higher molecular masses compounds, up to a mass of $420 \mathrm{HC}$ eq. The second one, centred at $535 \mathrm{~g} / \mathrm{mol} \mathrm{HC}$ eq., corresponded to triglycerides, with a mass distribution lower than stearine but higher $\mathrm{Mw}$ compounds were also present. The GCXGC analysis described above only allowed to detect the compounds with molecular masses in the range $100-420 \mathrm{~g} / \mathrm{mol}$.

\subsection{HTL conversion of Spirugrass}

In our former work [2], we have demonstrated that the HTL treatment of Spirulina sp. residues led to a hydrophobic fraction showing viscoelastic properties similar to an elastomer-rich bitumen. Interestingly, the Algosource Technologies Company provided us with Spirugrass, which is characterized by a lipid content lower than previously. We have thus studied in this 
paper the HTL conversion of this new residue under different operating conditions and in the presence of catalysts, to tune the rheological properties of the different bio-binders. For all HTL experiments presented here, the temperature was fixed at $260{ }^{\circ} \mathrm{C}$ and we have studied the influence of (i) the addition of a lipid-rich Spirugrass extract, (ii) the presence of a catalyst, (iii) the biomass loading for a same catalyst and (iv) the reaction time (from $15 \mathrm{~min}$ to $7 \mathrm{~h}$ ).

The yields obtained for HTL reactions and repeatability were assessed as explained in the Materials and Methods section. The obtained yields (Figure 1) were in the same range as those reported (42-48 wt \%) for HTL of Spirulina sp. [29,30].

As shown in Figure 1, the presence of a catalyst had little influence on the yield of the hydrophobic fraction and no significant difference was observed among the different catalysts $\left(\mathrm{ZrO}_{2}, \mathrm{CeO}_{2}\right.$, cerium nitrate). The highest yields (ca. 48 wt \%) were obtained using 1 wt \% of $\mathrm{Ce}\left(\mathrm{NO}_{3}\right)_{2} \cdot 6 \mathrm{H}_{2} \mathrm{O}$.

To confirm the interest of dispersed catalysis, oxide precursors like $\mathrm{Ba}\left(\mathrm{NO}_{3}\right)_{2}$ and $\mathrm{Fe}\left(\mathrm{NO}_{3}\right)_{3} \cdot 9 \mathrm{H}_{2} \mathrm{O}$ were tested (they are transformed in situ into the metal oxides or hydrohydes during $\mathrm{HTL}$ ) but both hydrophobic fractions obtained exhibited a solid texture and did not turn into viscous liquids even if they were heated up to $100^{\circ} \mathrm{C}$. Consequently, these samples could not be characterized in terms of rheology, and are useless as a road binder.

\subsection{Chemical characterization of the biocrude}

Each HTL hydrophobic fraction oil was analyzed by CHONS elemental analysis and the resulting $\mathrm{O} / \mathrm{C}, \mathrm{H} / \mathrm{C}$ and $\mathrm{N} / \mathrm{C}$ atomic ratio were plotted in a general van Krevelen diagram (Figure 2) and compared with the initial Spirugrass and the Spirugrass solvent extract.

A decrease in the N/C atomic ratio from 1.16 to ca. 0.8 was invariably observed for all HTL hydrophobic fractions (see size of the balls in Figure 2), whatever the experimental conditions in terms of reaction time, and presence or absence of any catalyst, suggesting the degradation of some nitrogen compounds under HTL conditions (Table S1). It can be also noticed that the $\mathrm{O} / \mathrm{C}$ atomic ratio of the different hydrophobic fractions after HTL were lower than in the initial Spirugrass (a reported advantage of the HTL process), and even lower when no catalyst was used. This last result is not totally in accordance with previous studies where heterogeneous catalysts like supported CoMo, $\mathrm{Ni}$ or Pt catalysts were found to lower $\mathrm{O} / \mathrm{C}$ ratio and improve $\mathrm{HHV}[8,31]$ but it could be originated from the lower temperature used here for the HTL. While extraction of Spirugrass with $\mathrm{CHCl}_{3} / \mathrm{MeOH}$ also reduced the nitrogen and oxygen content, the 
hydrogen content was however higher compared to HTL. However, the entrapment of the catalyst in the hydrophobic fraction might result in potential errors in the measurement of the $\mathrm{C}, \mathrm{H}, \mathrm{O}, \mathrm{N}$, and $\mathrm{S}$ content by elemental analysis, making not obvious the comparison of the results when a catalyst is used or not. The $\mathrm{O} / \mathrm{C}$ value is important for estimating the degree of deoxygenation taking place during the HTL of the microalgae residue, although the obtained values are still far from those reported for a conventional petroleum bitumen (O/C: 0,01) [32]. In conclusion, it is difficult to rationalize the elemental analysis results as the presence of catalyst increased inaccuracies in the sampling. The only clear tendency is the strong decrease of $\mathrm{O}$ and $\mathrm{N}$ in the HTL oil compared to the Spirugrass residue.

Then, the oily part of the hydrophobic fractions was analysed by GCxGC-MS. This technique is very powerful to separate and identify components in complex mixtures but limited to volatile compounds, therefore only the light part of the samples could be analysed. The detected components represented 1 to $4 \mathrm{wt} \%$ of the oil thus they were not quantified by using a $\mathrm{FI}$ detector for that reason. In nearly all cases, except when the HTL experiments were run for 7h, the GCxGC analysis displayed approximately the same compounds and families: alkanes $\left(C_{17}\right)$, alkenes $\left(\mathrm{C}_{18}-\mathrm{C}_{20}\right), \mathrm{N}$-cyclic compounds such as, pyrroles, pyrazines, piperazines, diketopiperazines, pyrrolidines, and fatty molecules like hexadecanoic acid (palmitic acid), ketones (e.g., $\mathrm{C}_{18} \mathrm{H}_{36} \mathrm{O}$ ), amides, esters and morpholine (Figure 3 and Figures $\mathrm{S} 5$ and $\mathrm{S6}$ ). This qualitative analysis on a restricted part of the oil, does not show significant change when using any of the catalysts after $1 \mathrm{~h}$ reaction. Most of these compounds can originate from the different reactions occurring between the bio-molecules under HTL conditions. For instance, most of alkanes and alkenes likely resulted from the decarboxylation of fatty acids. However, here as we are using a residue, and since heptadecane was shown to be present in the Spirugrass extract obtained by $\mathrm{CHCl}_{3} / \mathrm{MeOH}$ extraction, part of alkanes are probably already present in the residue and were just released and not much affected by HTL. Pyrazines usually comes from the Maillard reaction [33-36] between sugars and amino acids or amines, and pyrroles derive from the thermal degradation of chlorophyll and proteins. Diketopiperazines typically comes from the depolymerization and cyclization of peptides, while some ketones might be formed from the vicinal hydroxy groups in carbohydrates after dehydration and isomerization or from the ketonization reaction between two carboxylic acids [14,20$22,37,38]$. The increase of the reaction time with both $\mathrm{CeO}_{2}$ and $\mathrm{ZrO}_{2}$ catalysts had a deeper 
impact on the HTL oil composition (Figures S7 and S8) and that could be attributed to the slow kinetics when using catalyst in this middle. Effectively, after $7 \mathrm{~h}$ of reaction, the number of detected volatiles compounds decreased strongly. Even if it was not quantified as mentioned above, we can observe that notably the $\mathrm{N}$-cyclic compounds including pyrazinediones had been mostly removed, while alkanes/alkenes and fatty amides/morpholines remained. This suggests that more condensation reaction with the lipidic fraction took place or on the contrary that longer reaction time favoured degradation of the small molecules present after $1 \mathrm{~h}$. Some samples of HTL aqueous fractions were also qualitatively analysed by GCxGC-MS, showing that the reaction time has also an influence on their composition, when using a $\mathrm{ZrO}_{2}$ or $\mathrm{CeO}_{2}$ catalyst (Figure S9). After $1 \mathrm{~h}$, the main components of the aqueous fraction were piperazinediones with alkyl and benzyl substituents similarly observed in the hydrophobic fraction, in addition to pyrazines and pyrrolidinediones. In contrast, after $7 \mathrm{~h}$, the amount of carboxylic acids, pyrazines and pyrrolidinedione families was respectively higher while lower for piperazinedione.

The molecular weight distribution of the bio-oil is a very important feature regarding its application as asphalt binder for aggregates. GPC was used to investigate the influence of the different catalysts as well as the effect of the HTL reaction time (Figure 4 and Figure S10).

In the presence of catalyst and after $1 \mathrm{~h} \mathrm{HTL}$ reaction, the distribution of the molar masses does not show significant differences with the HTL realized without catalyst. The HTL of Spirugrass enriched with lipid fraction presents the same distribution than in Spirugrass HTL experiments (Figure S10).

Interestingly, an increase of the amount of high molecular weight products was observed using a $\mathrm{CeO}_{2}$ catalyst for $7 \mathrm{~h}$ of reaction (Figure 4), and to a lower extent in the case of $\mathrm{Ce}\left(\mathrm{NO}_{3}\right)_{3}$ and $\mathrm{ZrO}_{2}$ (not shown for clarity). The same trend as $\mathrm{ZrO}_{2}$ and $\mathrm{Ce}\left(\mathrm{NO}_{3}\right)_{3}$ was also found when increasing reaction time in the absence of catalyst, suggesting that this phenomenon is rather resulting from a longer reaction time which favours condensation reactions not necessarily promoted by catalysts. This was in full agreement with the average molecular weight (Mw) which slightly increased when increasing the reaction time (Table S2). In addition, most of the HTL samples displayed a similar distribution with a major contribution located at $304 \mathrm{~g} / \mathrm{mol}$ HC. eq. (stearic acid area) like for the Spirugrass extract. However, the Spirugrass extract displayed a major contribution at $535 \mathrm{~g} / \mathrm{mol}$ (triglyceride area, Figure S4) while the HTL experiment with and without catalyst showed a large contribution in the $400-800 \mathrm{~g} / \mathrm{mol} \mathrm{HC}$. 
eq. range with a significant peak around $505 \mathrm{~g} / \mathrm{mol}$. When a Spirugrass extract was added to the initial biomass, with no catalyst, the resulting HTL oil showed an increase of the Mw value due to the higher concentration of initial lipids which might participate in condensation reactions.

In conclusion, the role of the chosen catalysts are still not clear at this stage, and contrarily to some previous papers, we did not observe much difference by using $\mathrm{Ce}$ - and Zr-based oxide catalysts except at longer reaction time, that is consistent with low kinetics rates of the catalysts. Due to the difficulties to characterize well the hydrophobic fractions in regards with the limits of the techniques used, it would be risky to make conclusions about the role and the choice of the catalysts. The literature evidences that other types of acidic, basic or metallic catalysts $[8,14,15]$ can change the chemical bio-oil composition but the evidence was only made on the volatile part of the bio-oil that usually represent only a few percentage of the whole biocrude. Thus, to quantify the chemical composition changes, further analysis such as FTICR-MS[6] are necessary but all the chemical characterization depends greatly of the nature of the feed and operating conditions used. Finally, we have seen by the analysis of the ashes content that inorganics as $\mathrm{Ca}, \mathrm{Fe}, \mathrm{Mg}$ and $\mathrm{P}$ are present in the residue (Figure $\mathrm{S} 1$ and $\mathrm{S} 2$ ). These species may have a catalytic effect or may poison the catalytic sites depending of the exact nature of the original components. This could explain the few differences observed between the hydrophobic fractions obtained with and without oxide catalysts.

\subsection{Rheological properties}

The rheological properties of the hydrophobic HTL fractions were measured as described in the Materials and Methods section. Under some conditions $\left(10 \%\right.$ of $\mathrm{CeO}_{2}$ at $1 \mathrm{~h}, 2 \%$ of $\mathrm{Ce}\left(\mathrm{NO}_{3}\right)_{3} .6 \mathrm{H}_{2} \mathrm{O}$ at $1 \mathrm{~h}, 1 \%$ of $\mathrm{Ce}\left(\mathrm{NO}_{3}\right)_{3} .6 \mathrm{H}_{2} \mathrm{O}$ at $15 \mathrm{~min}$ ) a non-fusible material was obtained, making impossible the measurements of their rheological properties. Then, the shear modulus IG*[ of these non-fusible fractions will be considered as constant with a value equal to $1 \mathrm{GPa}$ (organic matter modulus in the glassy state). Moreover, considering that HTL experiments with heterogeneous catalysts $\left(\mathrm{ZrO}_{2}\right.$ and $\left.\mathrm{CeO}_{2}\right)$ were performed using a $300 \mathrm{~mL}$ reactor whereas HTL experiments with an homogenous catalyst $\left(\mathrm{Ce}\left(\mathrm{NO}_{3}\right)_{3} .6 \mathrm{H}_{2} \mathrm{O}\right)$ were done in the $1000 \mathrm{~mL}$ reactor, the thermal reaction conditions could not be strictly considered as equal. For this reason, the two series of rheological results were interpreted independently. 
Concerning HTL experiments with heterogeneous catalysts, hydrophobic fractions obtained with $10 \%$ of $\mathrm{ZrO}_{2}$ during $1 \mathrm{~h}$ and $7 \mathrm{~h}$ and $10 \% \mathrm{CeO}_{2}$ during $7 \mathrm{~h}$ exhibit viscoelastic signatures, over a large temperature and frequency domain, similar to conventional bitumen. Indeed, as observed for conventional bitumen, the rheological data plotted in the Black space (Figure 5) showed a continuous curve from $90^{\circ} \mathrm{C}$, where the material is liquid, to $0{ }^{\circ} \mathrm{C}$, where the material is an elastic solid. The continuity of the curve indicated that the material molecular structures were thermally stable. However, even though the overall viscoelastic signature was similar to conventional bitumen, the stiffness of the HTL fractions measured at $1 \mathrm{~Hz}$ was largely higher than for bitumen (Figure 6) whatever the catalyst or the reaction time.

Concerning HTL experiments performed for $1 \mathrm{~h}$ in the presence of a homogeneous catalyst, the rheological data plotted in the Black space (Figure S11) showed again a viscoelastic liquid behaviour similar to conventional bitumen with a thermal molecular structure stability. However, the amount of $\mathrm{Ce}\left(\mathrm{NO}_{3}\right)_{3} \cdot 6 \mathrm{H}_{2} \mathrm{O}$ added to the reaction medium appeared to influence this viscoelastic signature leading to more elasticity for the hydrophobic fractions (showed by a phase angle decrease a given modulus value). This had a direct effect on the stiffness, as shown in Figure $\mathrm{S} 12$, increasing with the $\mathrm{Ce}\left(\mathrm{NO}_{3}\right)_{3} \cdot 6 \mathrm{H}_{2} \mathrm{O}$ content until a non-fusible material was obtained (i.e. above $1 \%$ of catalyst).

The influence of the reaction time was also investigated in the presence or without any catalyst. Interestingly, isochrones related to HTL performed in the presence of $\mathrm{ZrO}_{2}$ (Figure 6) showed a stiffness reduction when increasing the reaction time. This was confirmed in the case of $\mathrm{HTL}$ experiments without catalyst and in the presence of $1 \%$ of $\mathrm{Ce}\left(\mathrm{NO}_{3}\right)_{3} \cdot 6 \mathrm{H}_{2} \mathrm{O}$, for which a two decades modulus decrease (at $50^{\circ} \mathrm{C}$ ) was observed between $1 \mathrm{~h}$ and $7 \mathrm{~h}$ reaction times (Figure 7), leading to a rheological behaviour very close to conventional bitumen when experiments were carried out for $7 \mathrm{~h}$.

Finally, whatever the conditions applied (type of catalyst, amount of catalyst, reaction time), the complex modulus of each hydrophobic fraction was found to be higher than for petroleum bitumen, leading to stiffer materials with the only exception of the binder obtained after $7 \mathrm{~h}$ of HTL in the absence of catalyst, for which the stiffness was lower (Figure 8) and the rheological signature very close to bitumen. Reaction time, with and without catalyst, is the most predominant parameter on the hydrophobic fraction by reducing the stiffness. Considering the fact that the GPC shows an increase in the average molecular weight (Mw) for the $7 \mathrm{~h}$ experiment and, at the same time a decrease in the stiffness, one hypothesis would 
be that the solid residues (not analyzed in GPC) are hydrolyzed during HTL and finally were solubilized into the oily phase. Thus, even with an increase in the average molecular weight of the oily phase, the solid / oil ratio decreases and leads to a reduction in stiffness.

\section{Conclusion}

The treatment of Spirulina sp. residues was undertaken by HTL with various oxide catalysts and the reaction time was varied ( $1 \mathrm{~h}$ to $7 \mathrm{~h}$ ). Addition of zirconia or ceria during HTL had a mild impact on the composition of the hydrophobic fraction but allowed an enhancement of the average molecular weight when increasing the reaction time. The overall rheological signatures of the hydrophobic fractions obtained in the presence of the different catalysts or without any catalyst were not far from a classical bitumen. Indeed, Black diagrams showed that both bio- and conventional bitumen behave like Newtonian liquid at high temperatures and like an elastic solid at low temperatures. For both materials, the transition between liquid and solid state is smooth and continuous (isotherms in the Black diagrams overlapped). However, absolute values of the stiffness measured at $1 \mathrm{~Hz}$ for the different biobinders (at 20 ${ }^{\circ} \mathrm{C}, 1 \mathrm{~Hz},\left|\mathrm{G}^{*}\right|>4 \mathrm{E} 7 \mathrm{~Pa}$ ) remained largely above the value obtained for petroleum bitumen (at $20^{\circ} \mathrm{C}, 1 \mathrm{~Hz},\left|\mathrm{G}^{*}\right| \approx 5 \mathrm{E} 6 \mathrm{~Pa}$ ). The reaction time had important effects on composition and was found to promote condensation reactions. Besides, increasing reaction time led to diminution of the stiffness of the biobinder (at $20^{\circ} \mathrm{C}, 1 \mathrm{~Hz},\left|\mathrm{G}^{*}\right| \approx 5 \mathrm{E} 6 \mathrm{~Pa}$ ) which is very similar to a petroleum bitumen. Reaction time seems to have a huge importance on the solid to oil ratio in the biocrude which appeared to be the key parameter for the rheological properties.

Finally, the economic viability of this technology is under investigation and addresses different aspects : scaling-up of the process, studies on bio-bitumen aging, life-cycle analysis, and global cost analysis of the process and compared to petroleum bitumen.

\section{Acknowledgement}

This work received the financial support of ANR (Algoroute project, grant ANR-16-CE08-0017). Algosource company is acknowledged for providing the Spirugrass residue.

\section{Supplementary data}

Supplementary material related to this article can be found, in the online version, at xxx. 


\section{References}

[1] Audo M, Paraschiv M, Queffelec C, Louvet I, Hemez J, Fayon F, et al. Subcritical Hydrothermal Liquefaction of Microalgae Residues as a Green Route to Alternative Road Binders. Acs Sustain Chem Eng 2015;3:583-90. https://doi.org/10.1021/acssuschemeng.5b00088.

[2] Borghol I, Queffelec C, Bolle P, Descamps J, Lombard C, Lepine O, et al. Biosourced analogs of elastomer-containing bitumen through hydrothermal liquefaction of Spirulina sp microalgae residues. Green Chem 2018;20:2337-44. https://doi.org/10.1039/c8gc00094h.

[3] Ding $Y$, Shan B, Cao X, Liu Y, Huang M, Tang B. Development of bio oil and bio asphalt by hydrothermal liquefaction using lignocellulose. J Clean Prod 2021;288:125586. https://doi.org/10.1016/j.jclepro.2020.125586.

[4] Mahssin ZY, Zainol MM, Hassan NA, Yaacob H, Puteh MH, Saidina Amin NA. Hydrothermal liquefaction bioproduct of food waste conversion as an alternative composite of asphalt binder. J Clean Prod 2021;282:125422. https://doi.org/10.1016/j.jclepro.2020.125422.

[5] Nagappan S, Bhosale RR, Nguyen DD, Chi NTL, Ponnusamy VK, Woong CS, et al. Catalytic hydrothermal liquefaction of biomass into bio-oils and other value-added products - A review. Fuel 2021;285:119053. https://doi.org/10.1016/j.fuel.2020.119053.

[6] Zhang B, He Z, Chen H, Kandasamy S, Xu Z, Hu X, et al. Effect of acidic, neutral and alkaline conditions on product distribution and biocrude oil chemistry from hydrothermal liquefaction of microalgae. Bioresour Technol 2018;270:129-37. https://doi.org/10.1016/j.biortech.2018.08.129.

[7] Ross AB, Biller P, Kubacki ML, Li H, Lea-Langton A, Jones JM. Hydrothermal processing of microalgae using alkali and organic acids. Fuel 2010;89:2234-43. https://doi.org/10.1016/j.fuel.2010.01.025.

[8] Biller P, Riley R, Ross AB. Catalytic hydrothermal processing of microalgae: Decomposition and upgrading of lipids. Bioresour Technol 2011;102:4841-8. https://doi.org/10.1016/j.biortech.2010.12.113.

[9] Biller $P$, Ross AB. Potential yields and properties of oil from the hydrothermal liquefaction of microalgae with different biochemical content. Bioresour Technol 2011;102:215-25. https://doi.org/10.1016/j.biortech.2010.06.028.

[10] Zou S, Wu Y, Yang M, Kaleem I, Chun L, Tong J. Production and characterization of bio-oil from hydrothermal liquefaction of microalgae Dunaliella tertiolecta cake. Energy 2010;35:5406-11. https://doi.org/10.1016/j.energy.2010.07.013. 
[11] Jena U, Das KC, Kastner JR. Comparison of the effects of Na2CO3, Ca-3(PO4)(2), and NiO catalysts on the thermochemical liquefaction of microalga Spirulina platensis. Appl Energy 2012;98:36875. https://doi.org/10.1016/j.apenergy.2012.03.056.

[12] Duan P, Savage PE. Hydrothermal Liquefaction of a Microalga with Heterogeneous Catalysts. Ind Eng Chem Res 2011;50:52-61. https://doi.org/10.1021/ie100758s.

[13] Yang C, Jia L, Chen C, Liu G, Fang W. Bio-oil from hydro-liquefaction of Dunaliella salina over Ni/REHY catalyst. Bioresour Technol 2011;102:4580-4. https://doi.org/10.1016/j.biortech.2010.12.111.

[14] Chen Y, Wu Y, Ding R, Zhang P, Liu J, Yang M, et al. Catalytic Hydrothermal Liquefaction of D. tertiolecta for the Production of Bio-Oil over Different Acid/Base Catalysts. Aiche J 2015;61:111828. https://doi.org/10.1002/aic.14740.

[15] Xu Y, Zheng X, Yu H, Hu X. Hydrothermal liquefaction of Chlorella pyrenoidosa for bio-oil production over Ce/HZSM-5. Bioresour Technol 2014;156:1-5. https://doi.org/10.1016/j.biortech.2014.01.010.

[16] Rahman NAA, Fermoso J, Sanna A. Effect of Li-LSX-zeolite on the in-situ catalytic deoxygenation and denitrogenation of Isochrysis sp. microalgae pyrolysis vapours. Fuel Process Technol 2018;173:253-61. https://doi.org/10.1016/j.fuproc.2018.01.020.

[17] Xu D, Lin G, Guo S, Wang S, Guo Y, Jing Z. Catalytic hydrothermal liquefaction of algae and upgrading of biocrude: A critical review. Renew Sustain Energy Rev 2018;97:103-18. https://doi.org/10.1016/j.rser.2018.08.042.

[18] Li J, Fang X, Bian J, Guo Y, Li C. Microalgae hydrothermal liquefaction and derived biocrude upgrading with modified SBA-15 catalysts. Bioresour Technol 2018;266:541-7. https://doi.org/10.1016/j.biortech.2018.07.008.

[19] Galadima A, Muraza O. Hydrothermal liquefaction of algae and bio-oil upgrading into liquid fuels: Role of heterogeneous catalysts. Renew Sustain Energy Rev 2018;81:1037-48. https://doi.org/10.1016/j.rser.2017.07.034.

[20] Maag AR, Paulsen AD, Amundsen TJ, Yelvington PE, Tompsett GA, Timko MT. Catalytic Hydrothermal Liquefaction of Food Waste Using CeZrOx. Energies 2018;11:564. https://doi.org/10.3390/en11030564.

[21] Gaertner CA, Serrano-Ruiz JC, Braden DJ, Dumesic JA. Catalytic coupling of carboxylic acids by ketonization as a processing step in biomass conversion. J Catal 2009;266:71-8. https://doi.org/10.1016/j.jcat.2009.05.015.

[22] Gärtner CA, Serrano-Ruiz JC, Braden DJ, Dumesic JA. Catalytic Upgrading of Bio-Oils by Ketonization. ChemSusChem 2009;2:1121-4. https://doi.org/10.1002/cssc.200900178. 
[23] Lee Y, Choi J-W, Suh DJ, Ha J-M, Lee C-H. Ketonization of hexanoic acid to diesel-blendable 6undecanone on the stable zirconia aerogel catalyst. Appl Catal Gen 2015;506:288-93. https://doi.org/10.1016/j.apcata.2015.09.008.

[24] Bligh EG, Dyer WJ. A rapid method of total lipid extraction and purification. Can J Biochem Physiol 1959;37:911-7.

[25] Antelo FS, Costa JAV, Kalil SJ. Thermal degradation kinetics of the phycocyanin from Spirulina platensis. Biochem Eng J 2008;41:43-7. https://doi.org/10.1016/j.bej.2008.03.012.

[26] Paoletti C, Pushparaj B, Florenzano G, Capella P, Lercker G. Unsaponifiable matter of green and blue-green algal lipids as a factor of biochemical differentiation of their biomasses: I. Total unsaponifiable and hydrocarbon fraction. Lipids 1976;11:258-65. https://doi.org/10.1007/BF02544051.

[27] Babadzhanov AS, Abdusamatova N, Yusupova FM, Faizullaeva N, Mezhlumyan LG, Malikova MK. Chemical composition of Spirulina platensis cultivated in Uzbekistan. Chem Nat Compd 2004;40:276-9. https://doi.org/10.1023/B:CONC.0000039141.98247.e8.

[28] Muhling M, Belay A, Whitton BA. Variation in fatty acid composition of Arthrospira (Spirulina) strains. J Appl Phycol 2005;17:137-46. https://doi.org/10.1007/s10811-005-7213-9.

[29] Gai C, Zhang Y, Chen W-T, Zhang P, Dong Y. An investigation of reaction pathways of hydrothermal liquefaction using Chlorella pyrenoidosa and Spirulina platensis. Energy Convers Manag 2015;96:330-9. https://doi.org/10.1016/j.enconman.2015.02.056.

[30] Toor SS, Reddy H, Deng S, Hoffmann J, Spangsmark D, Madsen LB, et al. Hydrothermal liquefaction of Spirulina and Nannochloropsis salina under subcritical and supercritical water conditions. Bioresour Technol 2013;131:413-9. https://doi.org/10.1016/j.biortech.2012.12.144.

[31] Duan P, Savage PE. Hydrothermal Liquefaction of a Microalga with Heterogeneous Catalysts. Ind Eng Chem Res 2011;50:52-61. https://doi.org/10.1021/ie100758s.

[32] Lesueur D. The colloidal structure of bitumen: Consequences on the rheology and on the mechanisms of bitumen modification. Adv Colloid Interface Sci 2009;145:42-82. https://doi.org/10.1016/j.cis.2008.08.011.

[33] Qiu Y, Aierzhati A, Cheng J, Guo H, Yang W, Zhang Y. Biocrude Oil Production through the Maillard Reaction between Leucine and Glucose during Hydrothermal Liquefaction. Energy Fuels 2019;33:8758-65. https://doi.org/10.1021/acs.energyfuels.9b01875.

[34] Fan $\mathrm{Y}$, Hornung U, Dahmen N, Kruse A. Hydrothermal liquefaction of protein-containing biomass: study of model compounds for Maillard reactions. Biomass Convers Biorefinery 2018;8:909-23. https://doi.org/10.1007/s13399-018-0340-8. 
[35] Zhang C, Tang X, Sheng L, Yang X. Enhancing the performance of Co-hydrothermal liquefaction for mixed algae strains by the Maillard reaction. Green Chem 2016;18:2542-53. https://doi.org/10.1039/c5gc02953h.

[36] Changi SM, Faeth JL, Mo N, Savage PE. Hydrothermal Reactions of Biomolecules Relevant for Microalgae Liquefaction. Ind Eng Chem Res 2015;54:11733-58. https://doi.org/10.1021/acs.iecr.5b02771.

[37] Torri C, Garcia Alba L, Samorì C, Fabbri D, Brilman DWF (Wim). Hydrothermal Treatment (HTT) of Microalgae: Detailed Molecular Characterization of HTT Oil in View of HTT Mechanism Elucidation. Energy Fuels 2012;26:658-71. https://doi.org/10.1021/ef201417e.

[38] Zhang Y. Hydrothermal Liquefaction to Convert Biomass into Crude Oil. Biofuels Agric Wastes Byprod 2010:201-32. https://doi.org/10.1002/9780813822716.ch10. 
Table 1. Specifications of oxide catalysts

\begin{tabular}{lcccc}
\hline Catalyst & Supplier & Description & BET SSA* $\left(\mathbf{m}^{2} / \mathbf{g}\right)$ & $\begin{array}{c}\text { Pore volume } \\
\left(\mathbf{c m}^{3} / \mathbf{g}\right)\end{array}$ \\
\hline $\mathrm{ZrO}_{2}$ Norpro & St Gobain & Ref. XZ16052 & 96 & 0,61 \\
$\mathrm{CeO}_{2}$-HSA10 & Solvay & $\begin{array}{c}\text { Undoped cerium } \\
\text { oxide }\end{array}$ & 109 & - \\
\hline
\end{tabular}

*BET Specific surface area

Table 2. Catalyst loading for HTL experiments

\begin{tabular}{|c|c|c|c|}
\hline Catalysts & $\begin{array}{l}\text { Wt\% based on } \\
\text { initial biomass }\end{array}$ & m (g) & Time (min) \\
\hline & \multirow{4}{*}{$10 \%$} & \multirow{4}{*}{2} & 60 \\
\hline 2102 & & & 420 \\
\hline \multirow{2}{*}{$\mathrm{CeO}_{2}$} & & & 60 \\
\hline & & & 420 \\
\hline \multirow{7}{*}{$\mathrm{Ce}\left(\mathrm{NO}_{3}\right)_{3} \cdot 6 \mathrm{H}_{2} \mathrm{O}$} & $0,1 \%$ (Ce) & 0.29 & \multirow{2}{*}{60} \\
\hline & $0.5 \%(\mathrm{Ce})$ & 1.49 & \\
\hline & \multirow{4}{*}{$1 \%(\mathrm{Ce})$} & \multirow{4}{*}{2.98} & 15 \\
\hline & & & 60 \\
\hline & & & 240 \\
\hline & & & 420 \\
\hline & $2 \%(\mathrm{Ce})$ & 5.96 & 60 \\
\hline
\end{tabular}


Table 3. Chemical data related to the Spirugrass used in this study and its extraction products using a $\left(\mathrm{MeOH} / \mathrm{CHCl}_{3}\right)$ mixture.

\begin{tabular}{|c|c|c|c|}
\hline & & Spirugrass & $\begin{array}{l}\text { Spirugrass extract } \\
\qquad\left(\mathrm{MeOH} / \mathrm{CHCl}_{3}\right)\end{array}$ \\
\hline \multicolumn{2}{|c|}{ Moisture (wt\%) } & 5.6 & - \\
\hline \multicolumn{2}{|c|}{ Ashes wt\% } & 6.5 & - \\
\hline$C$ & \multirow{5}{*}{ (wt\%) } & 45.5 & 61.9 \\
\hline $\mathrm{H}$ & & 6.4 & 9.0 \\
\hline $\mathrm{N}$ & & 8.5 & 5.0 \\
\hline$S$ & & 0.4 & 0.3 \\
\hline 0 & & 25.1 & 16.2 \\
\hline $\mathrm{O} / \mathrm{C}$ & \multirow{3}{*}{ At. } & 0.41 & 0.20 \\
\hline $\mathrm{H} / \mathrm{C}$ & & 1.68 & 1.74 \\
\hline $\mathrm{N} / \mathrm{C}$ & & 0.16 & 0.07 \\
\hline
\end{tabular}




\section{Figures Captions}

Figure 1. Yields of hydrophobic fractions after HTL reactions with Spirugrass residue

Figure 2. Van Krevelen diagram showing $\mathrm{O} / \mathrm{C}$ versus $\mathrm{H} / \mathrm{C}$ ratios and $\mathrm{N} / \mathrm{C}$ indicated by the size of balls of Spirugrass, Spirugrass extract and grouped HTL experiments

Figure 3. GCXGC-MS analysis of the volatile part of HTL bio-oils after $1 \mathrm{~h}$ residence time with $\mathrm{ZrO}_{2}$

Figure 4. GPC chromatogram of the various HTL oils after $1 \mathrm{~h}$, with and without catalyst.

Figure 5. Phase angle versus norm of the complex modulus for the hydrophobic fractions obtained from $\mathrm{HTL}$ in the presence of heterogeneous catalysts $\left(\mathrm{ZrO}_{2}, \mathrm{CeO}_{2}\right)$ and comparison with a conventional bitumen.

Figure 6. Norm of the complex modulus as a function of temperature, measured at $1 \mathrm{~Hz}$ for the hydrophobic fractions obtained from HTL in the presence of heterogeneous catalysts $\left(\mathrm{ZrO}_{2}, \mathrm{CeO}_{2}\right)$, and comparison with a conventional bitumen

Figure 7. Phase angle versus norm of the complex modulus for the hydrophobic fractions obtained from $\mathrm{HTL}$ in the presence of homogeneous catalysts $\left(\mathrm{Ce}\left(\mathrm{NO}_{3}\right)_{2}\right)$ and comparison with a conventional bitumen.

Figure 8. Norm of the complex modulus as a function of temperature, measured at $1 \mathrm{~Hz}$ for the hydrophobic fractions obtained from HTL in the presence of a homogeneous catalyst $\left(\mathrm{Ce}\left(\mathrm{NO}_{3}\right)_{3} \cdot 6 \mathrm{H}_{2} \mathrm{O}\right)$, by comparison with a conventional bitumen. Influence of the reaction time for a given amount of catalyst 


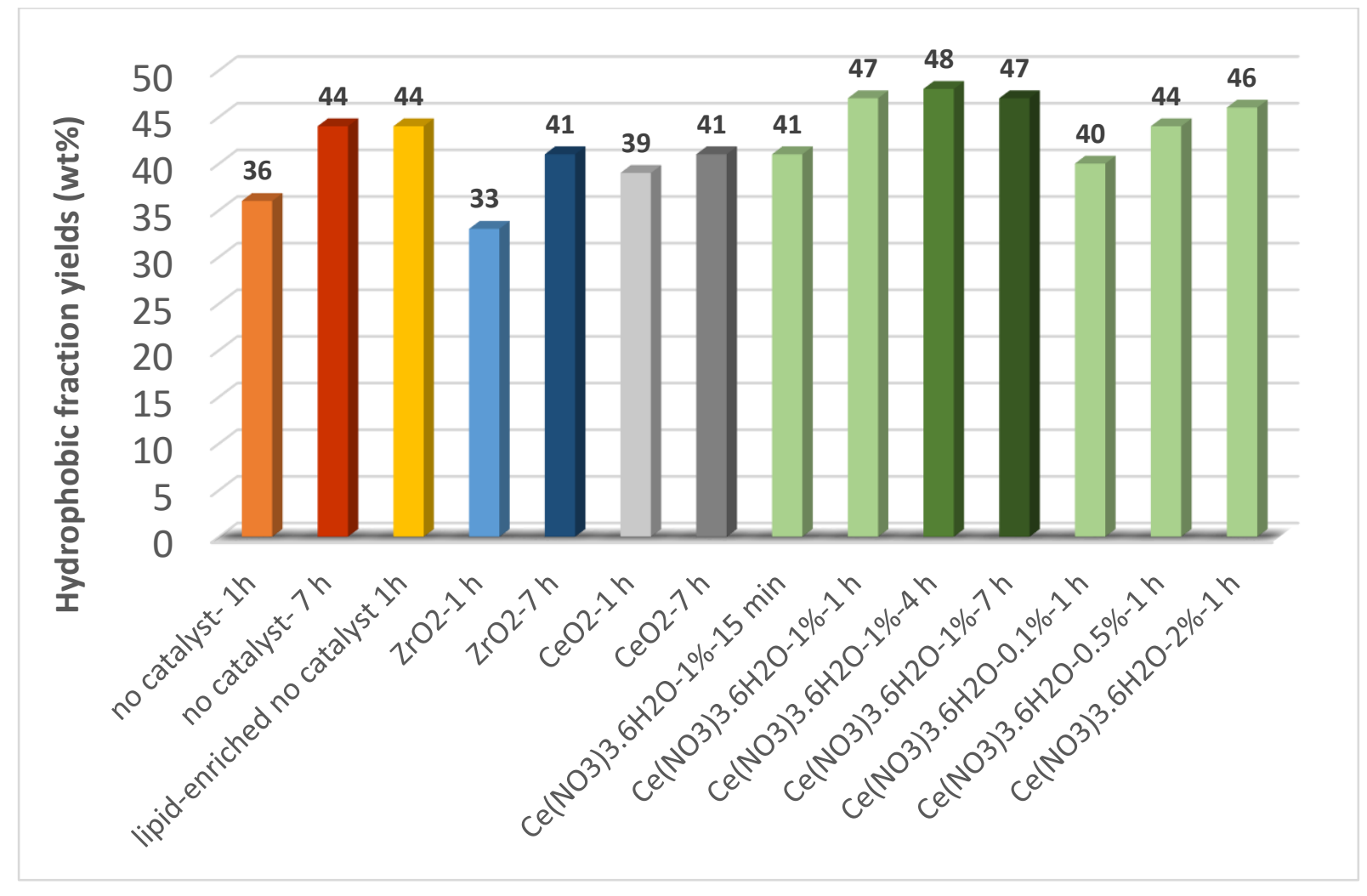

Figure 1. Yields of hydrophobic fractions after HTL reactions with Spirugrass residue 


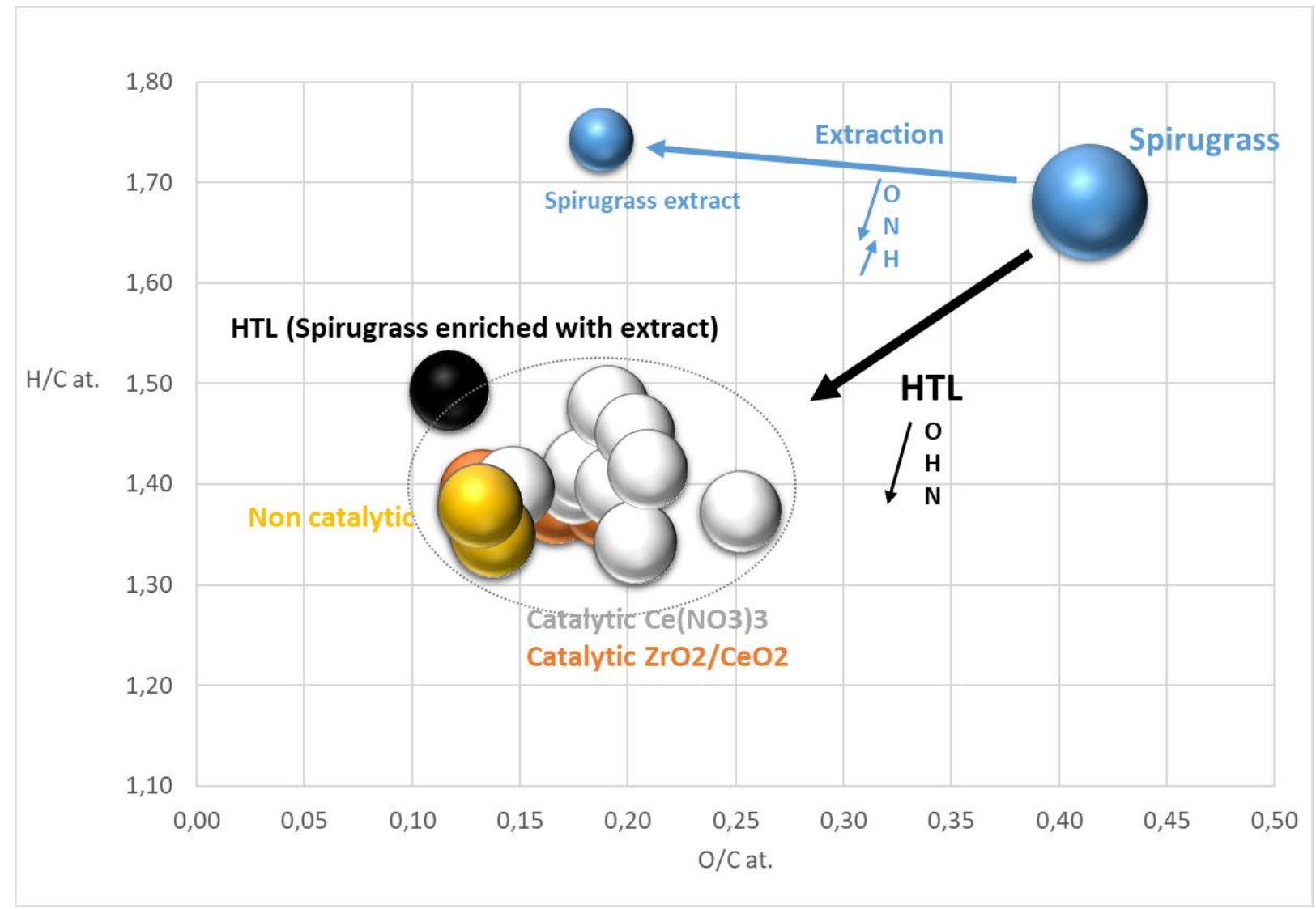

Figure 2. Van Krevelen diagram showing $\mathrm{O} / \mathrm{C}$ versus $\mathrm{H} / \mathrm{C}$ ratios and $\mathrm{N} / \mathrm{C}$ indicated by the size of balls of Spirugrass, Spirugrass extract and grouped HTL experiments 


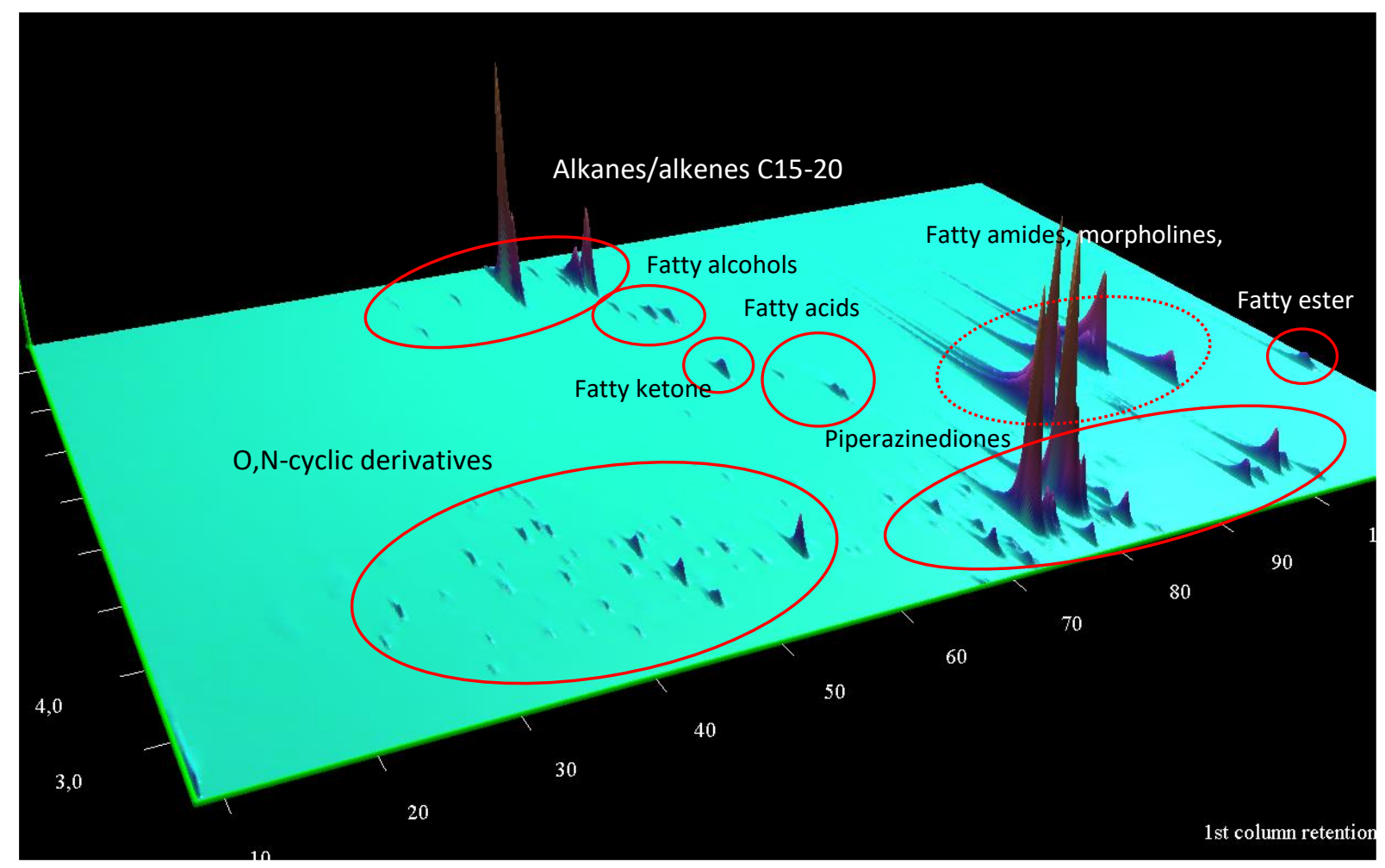

Figure 3. GCxGC-MS analysis of the volatile part of $\mathrm{HTL}$ bio-oils after $1 \mathrm{~h}$ residence time with $\mathrm{ZrO}_{2}$ catalyst 


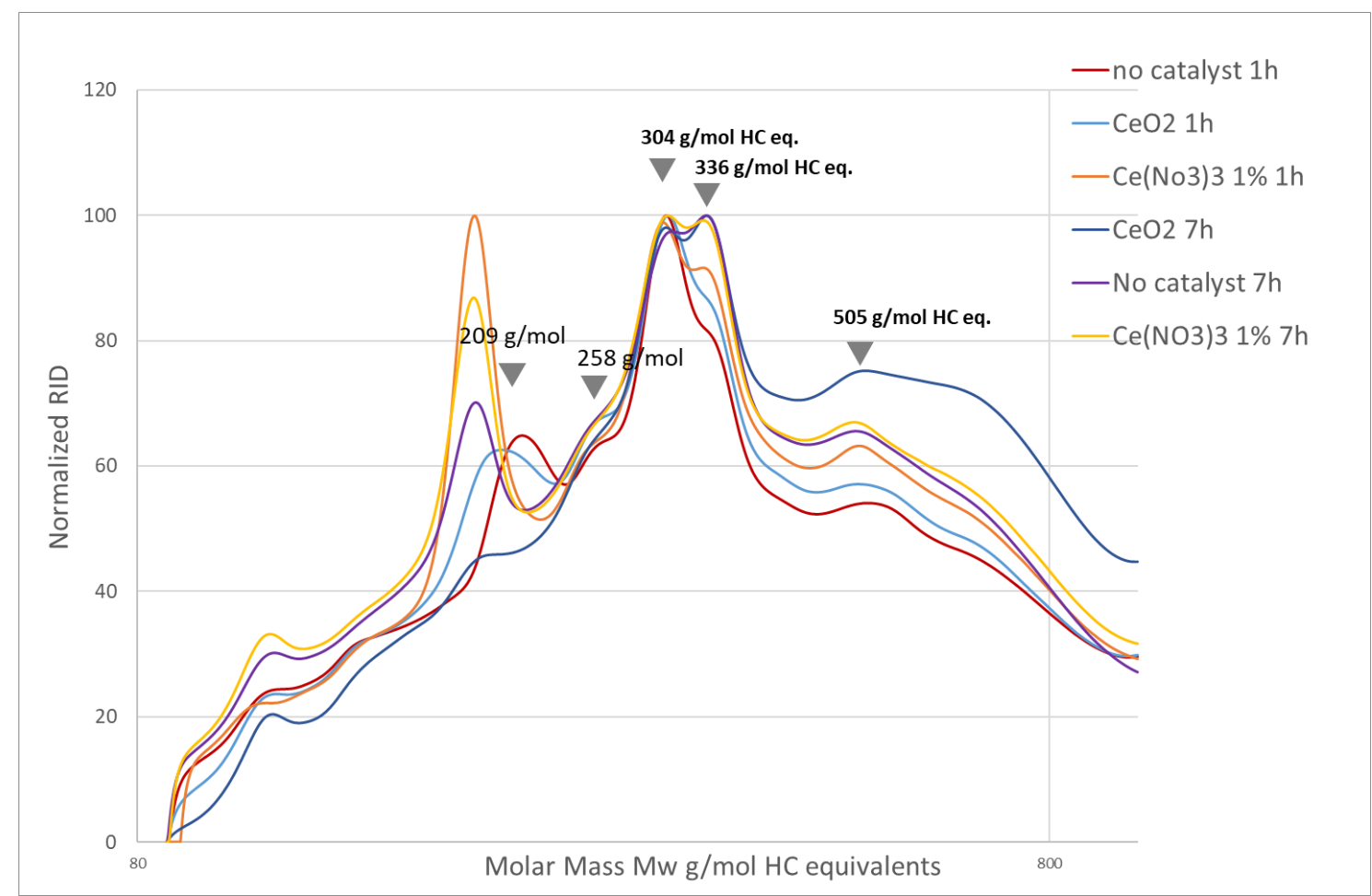

Figure 4. GPC chromatograms after 1 and $7 \mathrm{~h}$ reaction with and without Ce catalysts 


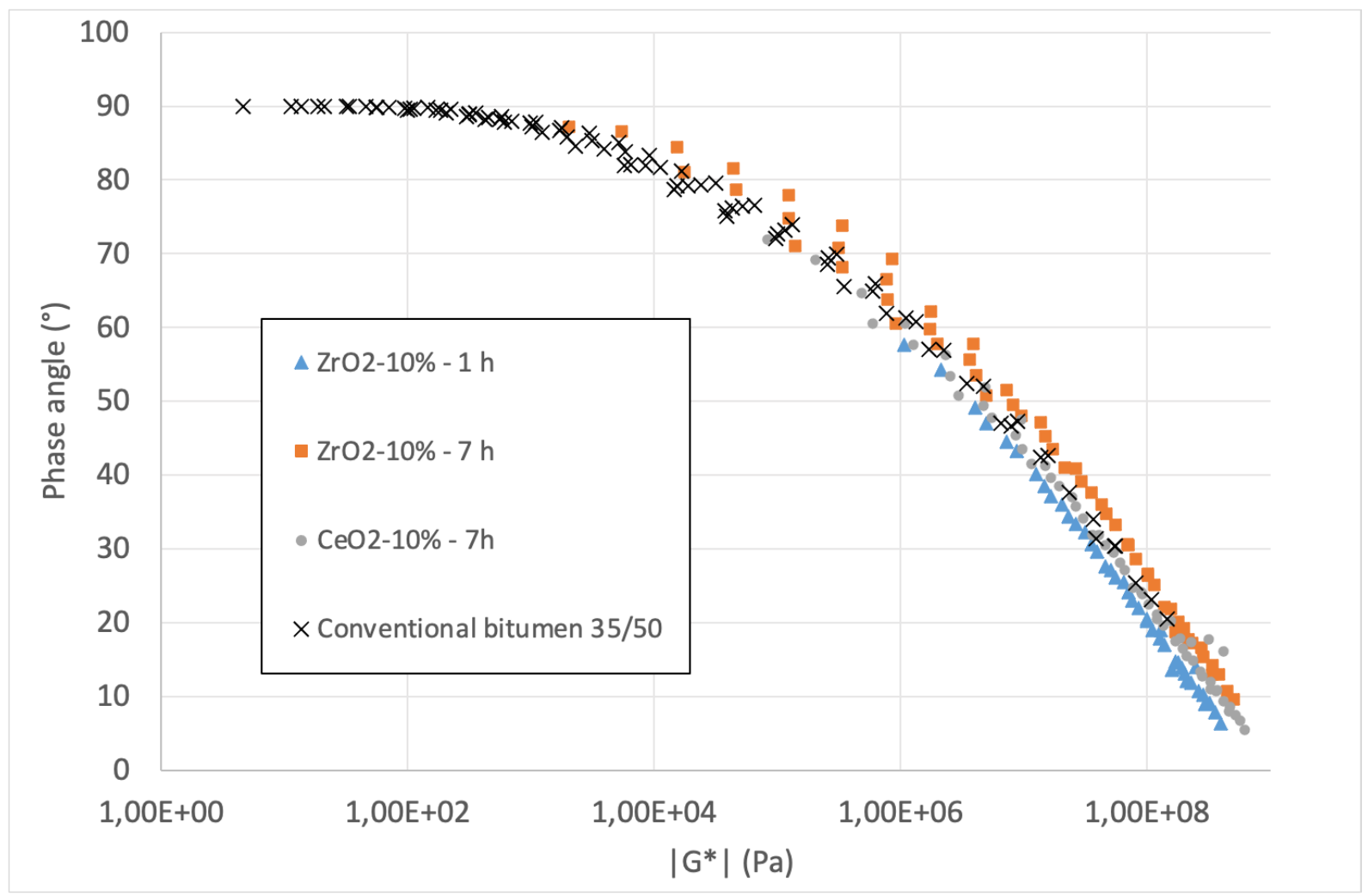

Figure 5. Phase angle versus norm of the complex modulus for the hydrophobic fractions obtained from $\mathrm{HTL}$ in the presence of heterogeneous catalysts $\left(\mathrm{ZrO}_{2}, \mathrm{CeO}_{2}\right)$ and comparison with a conventional bitumen. 


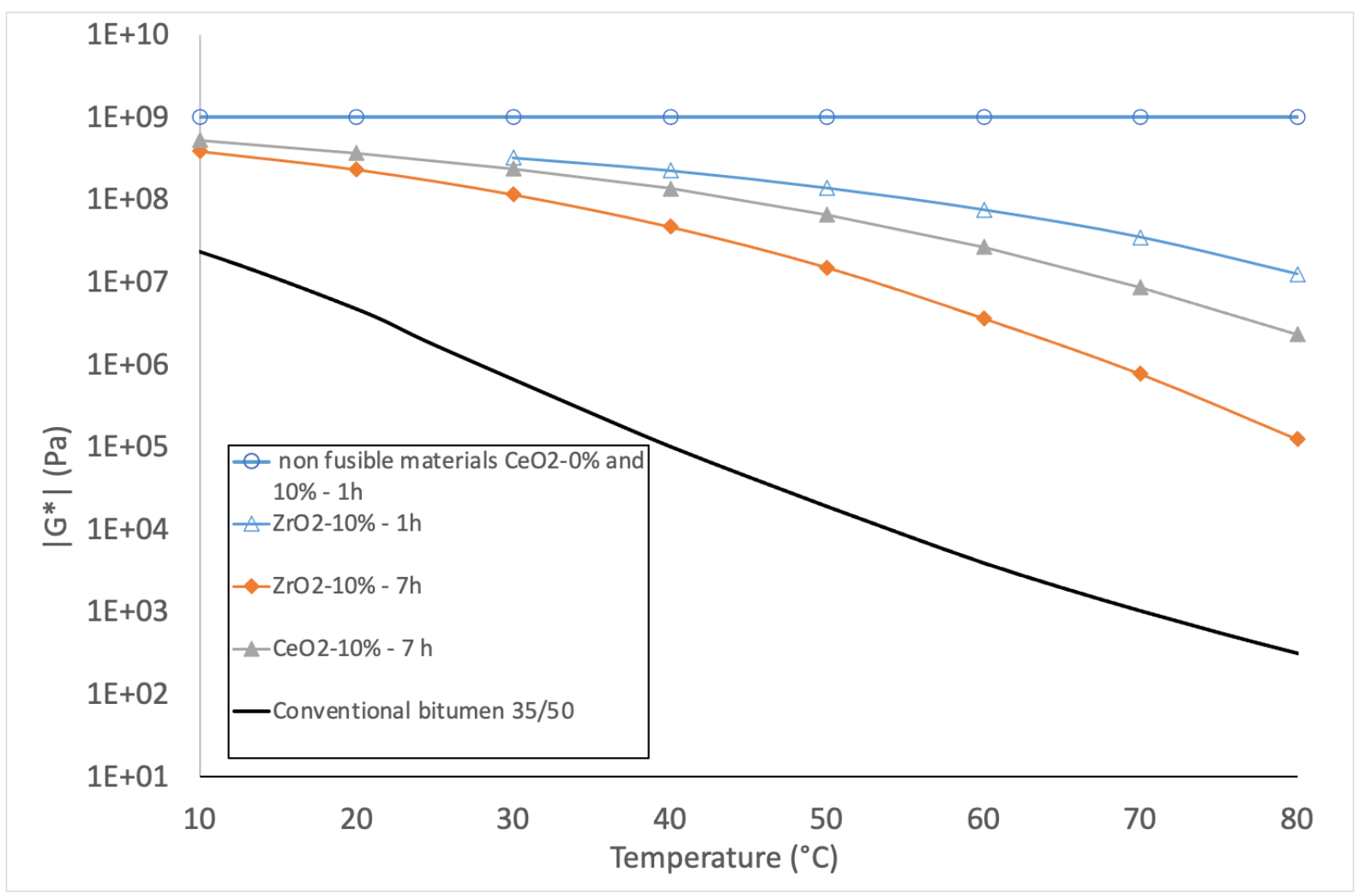

Figure 6. Norm of the complex modulus as a function of temperature, measured at $1 \mathrm{~Hz}$ for the hydrophobic fractions obtained from HTL in the presence of heterogeneous catalysts $\left(\mathrm{ZrO}_{2}, \mathrm{CeO}_{2}\right)$, and comparison with a conventional bitumen 


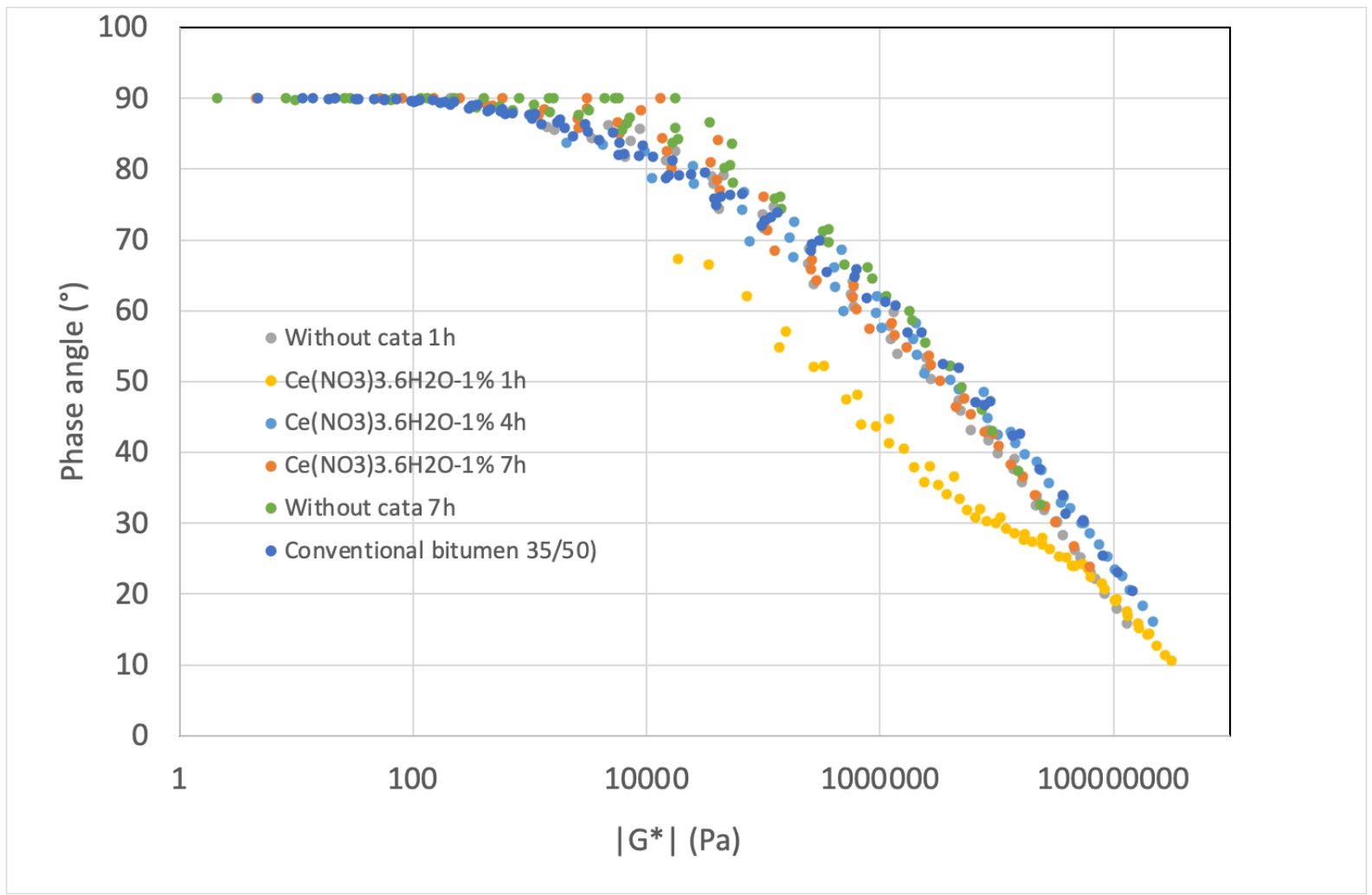

Figure 7. Phase angle versus norm of the complex modulus for the hydrophobic fractions obtained from HTL in the presence of homogeneous catalysts $\left(\mathrm{Ce}\left(\mathrm{NO}_{3}\right)_{2}\right)$ and comparison with a conventional bitumen. 


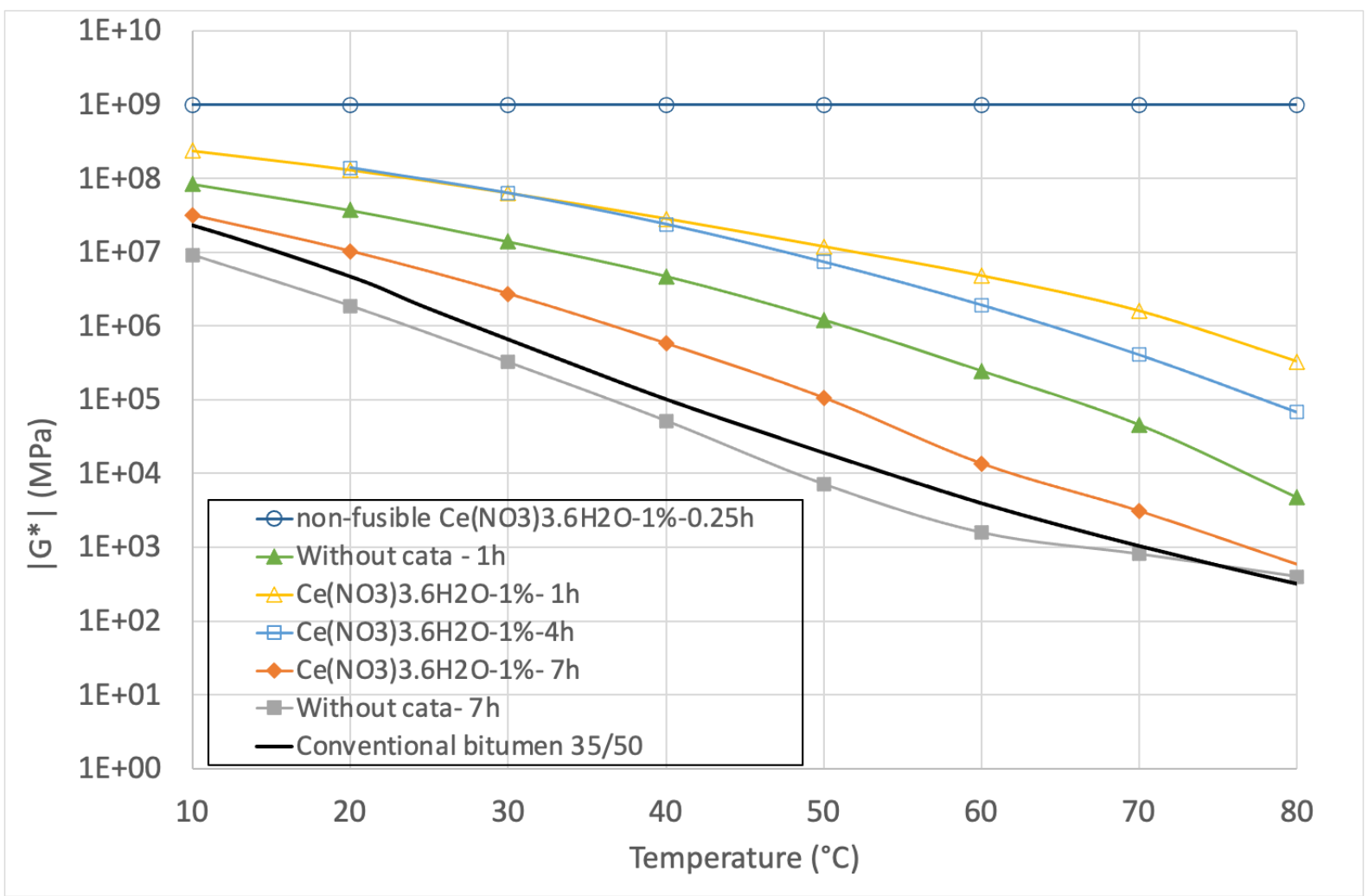

Figure 8. Norm of the complex modulus as a function of temperature, measured at $1 \mathrm{~Hz}$ for the hydrophobic fractions obtained from HTL in the presence of a homogeneous catalyst $\left(\mathrm{Ce}\left(\mathrm{NO}_{3}\right)_{3} \cdot 6 \mathrm{H}_{2} \mathrm{O}\right)$, by comparison with a conventional bitumen. Influence of the reaction time for a given amount of catalyst 